\begin{tabular}{|l|l|l||}
\hline \multicolumn{2}{|c|}{ PublisherInfo } \\
\hline \hline PublisherName & $:$ & BioMed Central \\
\hline \hline PublisherLocation & $:$ & London \\
\hline \hline PublisherImprintName & $:$ & BioMed Central \\
\hline \hline
\end{tabular}

\title{
A recipe for resurrection
}

\begin{tabular}{|l|l|l||}
\hline \multicolumn{2}{|c||}{ ArticleInfo } \\
\hline \hline ArticleID & $:$ & 4292 \\
\hline \hline ArticleDOI & $:$ & $10.1186 /$ gb-2001-3-1-reports0006 \\
\hline \hline ArticleCitationID & $:$ & reports0006 \\
\hline \hline ArticleSequenceNumber & $:$ & 24 \\
\hline \hline ArticleCategory & $:$ & Paper report \\
\hline \hline ArticleFirstPage & $:$ & 1 \\
\hline \hline ArticleLastPage & $:$ & 3 \\
\hline \hline & & RegistrationDate : 2001-11-6 \\
ArticleHistory & $:$ & Received \\
\hline ArticleCopyright & $:$ & BioMed Central Ltd2001-11-6 \\
\hline \hline ArticleGrants & $:$ & \\
\hline \hline ArticleContext & $:$ & 130593311 \\
\hline \hline
\end{tabular}




\section{Abstract}

Non-viable granulosa cells recovered post-mortem from a mouflon sheep have been used to clone the dead animal using a domestic sheep as a surrogate oocyte donor and mother

\section{Significance and context}

In yet another significant breakthrough for cloning, an international group has transferred granulosa cell nuclei from a mouflon, an endangered wild sheep, into enucleated domestic sheep oocytes, and produced a healthy mouflon lamb using a domestic sheep as the surrogate mother. This in itself would be notable, as it offers the intriguing prospect of being able artificially to increase the populations of endangered species that have a closely related common species. What makes this achievement particularly remarkable is that the donor animals had been dead for up to 24 hours before the tissue used for cloning was collected, and the cells that supplied the nuclei appeared to be nonviable.

\section{Key results}

Although the cloned sheep is phenotypically mouflon, its genotype is a hybrid of mouflon and domestic sheep in that its nuclear DNA is derived from the mouflon and its mitochondrial DNA (mtDNA) from the domestic sheep. Granulosa cells were mechanically dissociated from the cumulusoocyte complexes of two dead mouflon and injected into in vitro-matured enucleated sheep oocytes. Of the 23 injected oocytes, seven developed into blastocysts. These were transferred to four naturally cycling domestic ewes, resulting in two pregnancies. One pregnancy was lost between days 40 and 50, but the other continued to term and produced a healthy lamb which was phenotypically mouflon.

\section{Links}

Supplementary data to Nature Biotechnology 19:962-964 is freely available. 


\section{Conclusions}

This work shows that nuclei from post-mortem somatic cells can be used to produce viable clones of the donor, and that cross-species nuclear transfer is a viable method of reproducing the donor species. Although the authors are fairly guarded about the ramifications of this work and point to a number of gaps in knowledge, it is apparent that their findings could open the door for the 'genetic rescue' of other endangered species that have potential surrogate parents among domestic or wild stock. There are, of course, several issues that must be addressed before this type of approach can be attempted on any scale. The percentage of cloned embryos developing into viable offspring is still very low, and the long-term effects of combining genomic and heterologous mtDNA are unknown. There are also continuing questions over the long-term viability of populations of genetically identical individuals. In this case, it will not be known if the mouflons are fertile until they reach maturity.

\section{Reporter's comments}

Cloning is a big issue in biotechnology, with all kinds of speculation and hyperbole emanating from stakeholders and other interested parties. The media and general public have become both enamored and awed at its potential, but it has been difficult to judge just what the prospects might be and when they might be realized. The work by Loi et al. is exciting in that they have found that apparently nonviable cells, taken from a dead animal, can be used to produce a healthy clone of the deceased. What are the likely consequences? Will excited onlookers one day be gawping at sabre-toothed tigers in their local zoo, and will mastodons once more be trumpeting over the tundra? From a purely scientific point of view at least, this may not be as farfetched as it sounds. Mammoths are still occasionally unearthed in the frozen Arctic and are in such a good state of preservation that their meat is edible; the African elephant might be able to serve as a surrogate parent.

\section{Table of links}

Nature Biotechnology

Supplementary data to Nature Biotechnology 19:962-964

\section{References}

1. Loi P, Ptak G, Barboni B, Jr J Fulka, Cappai P, Clinton M: Genetic rescue of an endangered mammal by cross-species nucleartransfer using post-mortem somatic cells. Nat Biotechnol. 2001, 19: 962-964. 1087-0156 